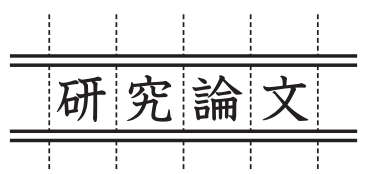

\title{
コーヒー滓を原料とした高硬度固形燃料の成型条件が燃焼特性に及ぼす影響

\author{
Influence of Production Condition of High Hardness Solid Fuel Made \\ from Coffee Residues on the Combustion Property
}

\author{
㴊端学**赤藤雄也**・水野 諭*・井田民男*・足立佑平** \\ Manabu FUCHIHATA, Yuya SHAKUTO, Satoru MIZUNO, Tamio IDA and Yuhei ADACHI
}

(Received December 26, 2012)

\begin{abstract}
Biomass is one of the sustainable energy sources and is the most suitable natural energy for storage and transport. We are suggesting a high hardness biomass briquette made from any plant biomass as an alternative coal coke. The high hardness biomass briquette is named 'Bio coke', described as 'BIC' below, and it achieves 10 to $20 \%$ substitution of coal coke for practical cupola furnace use. We, in the present study, examined the influence of composition on combustion property of BIC made from coffee residues. The coffee residues were assorted to outer skin (outer skin and pulp mixture, described as 'OS' below), inner skin (parchment and silver skin mixture, described as 'IS' below) and coffee bean grounds (instant coffee production residue, described as 'IC' below). BIC specimens were composed of IC100\%, IC50\%+OS50\% and IC50\%+IS50\%, OS100\% and IS100\%. Measurement of ignition delay (time from heating start to flaming combustion start), duration time of flaming combustion and char combustion, and thermogravimetry were conducted under $698 \mathrm{~K}$ air environment. As a result, the ignition delay and the duration time of char combustion were affected by not only combustion property of each component but crack generation condition during heating process. The ignition delay and the duration time of char combustion were shorten due to enlargement of reaction surface area caused by the crack generation. It is, additionally, considered that the crack generation condition could be controlled by mixing of components which have different thermal decomposition and combustion properties.
\end{abstract}

Key Words: Renewable Energy, Biomass Energy, Biomass Briquette, Bio Coke, Combustion

\section{1. 緒言}

近年、地球環境問題や化石燃料の急激な需要増加による 価格高騰および枯渇問題に対し、再生可能および廃棄物リ サイクルの観点から、新エネルギーの一つとしてバイオマ スが注目されており、その一つに植物性由来の固形燃料で あるバイオコークス（以下 BIC と表記）がある。 BIC は鉄 鋼溶解時に用いる石炭コークスの代替燃料として期待され ている。また、高密度で比較的燃焼速度の遅い性質から、 鉄鋼業に限らず農業用の温室ボイラーやごみ焼却等の熱源 としての利用が期待されている。

現在、BICの実用化に向けて鉄溶解炉内における燃焼実 験 ${ }^{1)}$ や農業用ボイラーなどでの実証試験が行われているが、 その燃焼特性に関する研究例は少なく ${ }^{2)}$ 、大気圧下におけ る一般的な燃焼挙動はほとんど明らかになっていない。今 後、BICのさらなる実用化、普及を図る上で、実用燃焼炉 において想定される運転状況下での燃焼特性を的確に把握 することは必要不可欠である。

BICの燃焼挙動は原料バイオマスの種類、粉砕粒度、成
型時含水率、成型温度・圧力等の成型条件により変化する ことが分かっている ${ }^{3)}$ 。本報では、コーヒー豆の精製がら、 抽出がらを原料として BIC を作製し、これらの配合が燃焼 特性に及ぼす影響を観察した。

\section{2. 実験装置および実験方法}

\subsection{BIC 成型方法}

BIC 成型にはバッチ式ホットプレス装置を使用した ${ }^{3)}$ 。 本実験で使用した BIC 成型装置の概略を Fig.1に示す。本 実験装置の主要部分は油圧プレス機（ASTRO PRODUCTS， プレス・ポートパワー・ベンダー)、シリンダ、ピストン、 電気管状炉、温度コントローラにより構成されている。

Fig.2に電気管状炉と成型用シリンダの詳細を示す。本 装置では、一度の成型工程において最大 3 つの BIC を同時 成型できる。内径 $20 \mathrm{~mm}$ のシリンダ内に、成型後のアスペ クト比が $1: 1$ となるように試料を一定量充填する。試料充 填後、油圧ジャッキによって $21.7 \mathrm{MPa} て ゙$ 加圧した状態で電 気管状炉（アサヒ理化製作所, ARF-50M）を温度コントロー ラ（アサヒ理化製作所, AMF-2PT）によって制御し、所定

* 近畿大学 理工学部 機械工学科（广 577-8502 大阪府東大阪市小若江 3-4-1）

Department of Mechanical Engineering, Faculty of Science and Engineering, Kinki University (3-4-1 Kowakae, Higashi-Osaka, Osaka, 577-8502 Japan) ** 近畿大学大学院 総合理工学研究科（ T 577-8502 大阪府東大阪市小若江 3-4-1)

Graduate School of Science and Engineering, Kinki University (3-4-1 Kowakae, Higashi-Osaka, Osaka, 577-8502 Japan) 


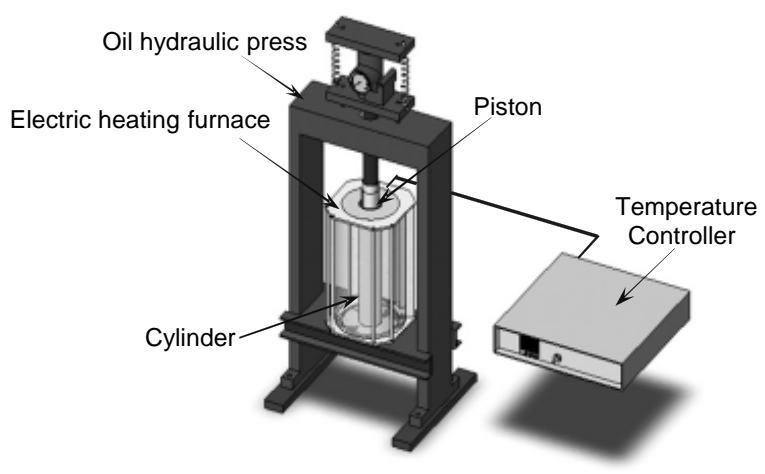

Fig. 1 BIC production rig

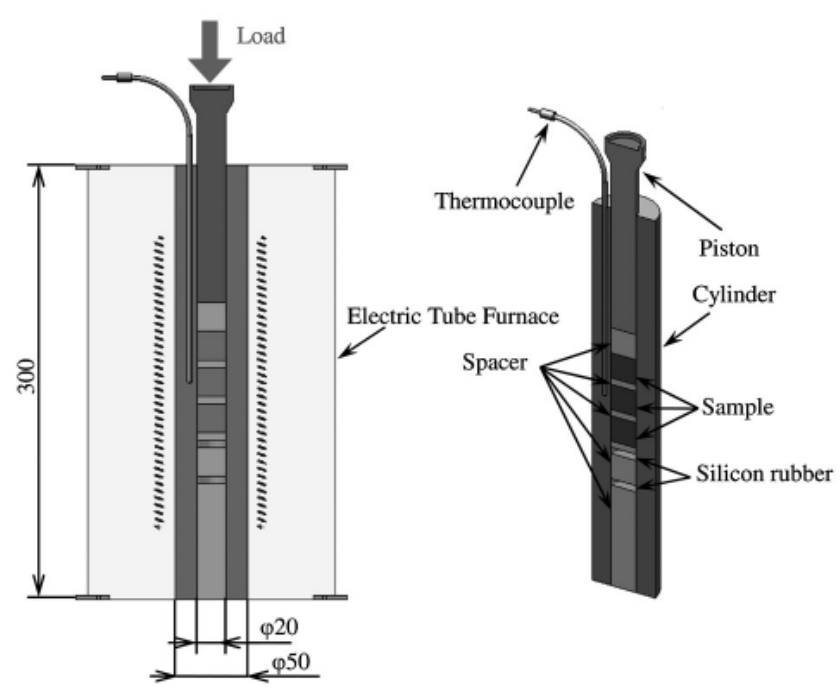

Fig. 2 BIC molding device

の成型温度に到達後 6.25 分間保持する。その後室温まで冷 却し、シリンダより取り出した。成型温度はシリンダ壁に 設けた穴にシース熱電対（Kタイプ，シース径 $3.2 \mathrm{~mm}$ )を 設置し、シリンダ中央部でモニタした。

\section{2 燃焼実験}

燃焼実験に使用した実験装置の概略図をFig.3に、燃焼 室の詳細を Fig.4に示す。燃焼室内温度は $\pm 5{ }^{\circ} \mathrm{C}$ の範囲で 温度設定が可能であり、燃焼室上部に設けた挿入口から試 料を挿入し、燃焼させる。側面からは石英ガラスを通して 内部観察が可能で、ビデオカメラによって燃焼挙動を撮影 した。

コンプレッサーにより供給される空気は流量を調節さ れた後、電熱ヒーター（東洋テクニカル, NCH-IML 100 $\mathrm{V} / 250 \mathrm{~W}$ ) により加熱され、電気管状炉（アサヒ理化製作 所, ARF-50M) 内へ流入する。電気管状炉でさらに加熱、 整流された高温空気は円筒型断熱材（外径 $90 \mathrm{~mm}$ 、内径 64

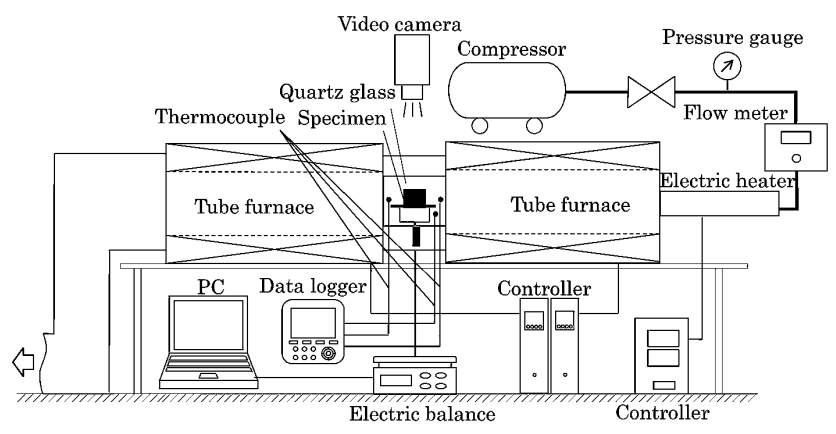

Fig. 3 Experimental apparatus

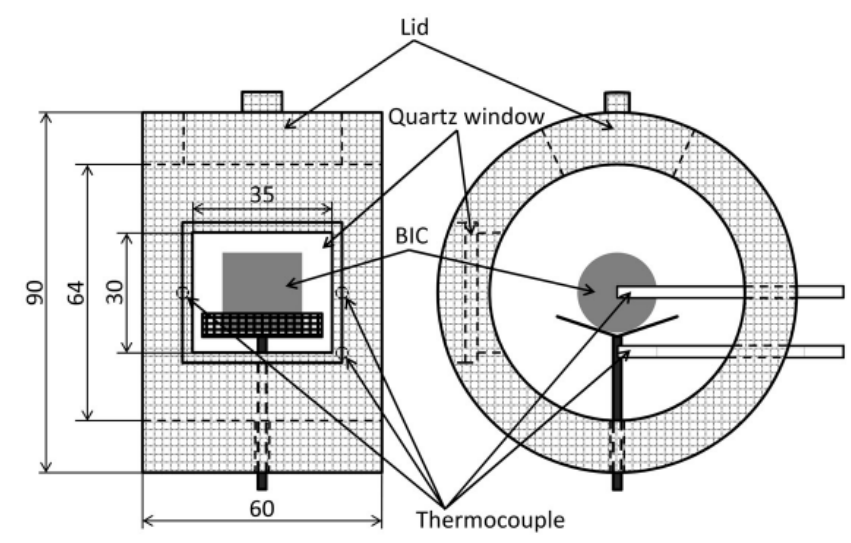

Fig. 4 Combustion chamber

mm）に覆われた燃焼室へ供給され、試料支持台に載せら れた試料を急速に加熱し、燃焼させる。試料支持台中央か

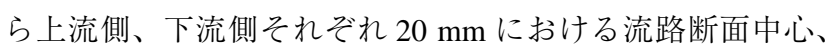
および上流側 $20 \mathrm{~mm}$ の流路断面中心から半径 $15 \mathrm{~mm}$ の点 に K 型熱電対を設置し、温度測定を行った。供給空気温度 の設定は、流路断面中心の測定值により行った。半径 15 $\mathrm{mm}$ の点の温度は流路中心の温度より約 $25 \mathrm{~K}$ 低くなってい る。本実験装置は熱天秤方式となっており、電子天秤（エー アンドディー, GX-4000, 読み取り精度 0.01 g）の質量測 定データをパソコンへ取り込むことで、燃焼中の試料の重 量変化を記録した。本実験では、試料投入から有炎燃焼開 始までの時間を着火遅れ、有炎燃焼開始から有炎燃焼終了 までを有炎燃焼期間、有炎燃焼終了からチャー燃焼終了ま でをチャー燃焼期間と定義した。チャー燃焼終了は、測定 した重量変化履歴から重量減少率を計算し、直近 5 分間の 平均重量減少率が毎分 $0.2 \%$ を下回った時点として判定し た。供給空気流量は $10 \mathrm{NL} / \mathrm{min}$ 一定、空気温度 $\mathrm{T}_{\mathrm{C}}=698 \mathrm{~K}$ として着火および然焼挙動の観察を行った。

\section{3. 実験結果および考察}

BIC 製造に用いた試料は、コーヒー豆（アラビカ種、ロ 
Table 1 Molding condition

\begin{tabular}{|l|c|c|c|c|c|}
\hline \multicolumn{1}{|c|}{ Specimen } & IC $100 \%$ & $\begin{array}{r}\text { IC } 50 \%+ \\
\text { AR-OS } 50 \%\end{array}$ & $\begin{array}{c}\text { IC } 50 \%+ \\
\text { ROB-OS } 50 \%\end{array}$ & $\begin{array}{c}\text { IC } 50 \%+ \\
\text { AR-IS } 50 \%\end{array}$ & $\begin{array}{c}\text { IC } 50 \%+ \\
\text { ROB - IS 50 \% }\end{array}$ \\
\hline Molding Temperature K & \multicolumn{5}{|l|}{413} \\
\hline Molding Pressure MPa & 9.85 & 9.75 & 9.76 & 9.92 & 9.85 \\
\hline Water content \% & 7.48 & 7.83 & 7.76 & 7.85 & 7.75 \\
\hline Weight g & 18.8 & 18.8 & 18.65 & 18.9 & 18.65 \\
\hline Diameter mm & 1.27 & 1.33 & 1.32 & 1.32 & 1.32 \\
\hline Hight mm &
\end{tabular}

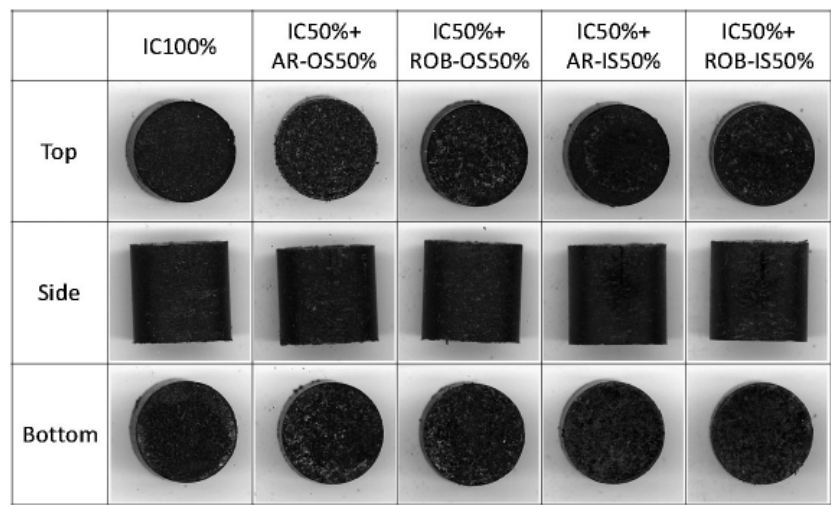

Fig. 5 Photographs of the BICs

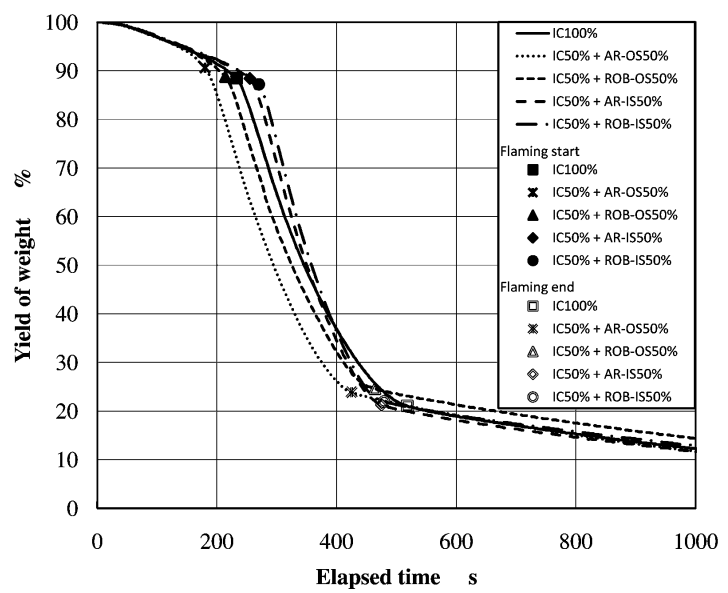

Fig. 6 Weight reduction curves for $\mathrm{Tc}=698 \mathrm{~K}$

Table 2 Combustion characteristic of mixed BICs

\begin{tabular}{|c|c|c|c|c|c|c|c|c|c|c|}
\hline & \multicolumn{3}{|c|}{ Ignition delay term } & \multicolumn{3}{|c|}{ Flaming combustion term } & \multicolumn{3}{|c|}{ Char combustion term } & \multirow[b]{2}{*}{$\begin{array}{l}\text { Ash } \\
\% w t\end{array}$} \\
\hline & $\begin{array}{c}\text { Duration } \\
\text { time } \\
\mathrm{s}\end{array}$ & $\begin{array}{c}\text { Weight } \\
\text { reduction } \\
\% \\
\%\end{array}$ & $\begin{array}{l}\text { Weight } \\
\text { reduction } \\
\text { rate } \\
\% / s\end{array}$ & $\begin{array}{c}\text { Duration } \\
\text { time } \\
\text { s }\end{array}$ & $\begin{array}{c}\text { Weight } \\
\text { reduction } \\
\% \\
\%\end{array}$ & $\begin{array}{l}\text { Weight } \\
\text { reduction } \\
\text { rate } \\
\% / s\end{array}$ & $\begin{array}{c}\text { Duration } \\
\text { time } \\
\mathrm{s} \\
\end{array}$ & $\begin{array}{c}\text { Weight } \\
\text { reduction } \\
\% \\
\%\end{array}$ & $\begin{array}{l}\text { Weight } \\
\text { reduction } \\
\text { rate } \\
\% / s\end{array}$ & \\
\hline IC $100 \%$ & 233 & 11.49 & 0.0493 & 285 & 67.44 & 0.237 & 1769 & 18.65 & 0.0105 & 2.41 \\
\hline $\begin{array}{c}\text { IC } 50 \%+A R \\
- \text { OS } 50 \%\end{array}$ & 180 & 9.39 & 0.0522 & 245 & 66.73 & 0.272 & 1530 & 20.05 & 0.0131 & 3.83 \\
\hline $\begin{array}{c}\text { IC } 50 \%+\text { ROB } \\
\text {-OS } 50 \%\end{array}$ & 214 & 11.22 & 0.0524 & 250 & 64.17 & 0.257 & 1713 & 20.23 & 0.0118 & 4.38 \\
\hline $\begin{array}{c}\text { IC } 50 \%+A R \\
\text {-IS } 50 \% \\
\end{array}$ & 255 & 11.59 & 0.0455 & 220 & 67.13 & 0.305 & 1792 & 19.36 & 0.0108 & 1.91 \\
\hline $\begin{array}{c}\text { IC } 50 \%+\text { ROB } \\
\text {-IS } 50 \%\end{array}$ & 270 & 12.79 & 0.0474 & 209 & 65.27 & 0.312 & 1854 & 19.23 & 0.0104 & 2.71 \\
\hline
\end{tabular}

ブスタ種。以下それぞれ AR、ROB と表記）の外皮（外皮、 果肉の混合物。以下 OS と表記)、中白皮（主に内果皮、銀 皮の混合物。以下 IS と表記)、および抽出がら（ブレンド インスタントコーヒー製品がら。以下 IC と表記）とした。 粉砕後、電動ふるいにより $1 \mathrm{~mm}$ 以下に分級し、IC $100 \%$ 、 IC $50 \%$ + AR - OS $50 \%$ 、IC $50 \%$ + ROB - OS $50 \%$ 、IC $50 \%$ + AR-IS $50 \%$ 、IC $50 \%$ + ROB-IS $50 \%$ の重量比で成型した。 それぞれの成型条件を Table 1 に、成型された BIC の外観 をFig.5に示す。全条件とも外観上は大きな違いはなく、
成型性は良好であった。

各 $\mathrm{BIC}$ の $\mathrm{Tc}=698 \mathrm{~K}$ における、有炎燃焼期間前後の重量 減少曲線を Fig.6に示す。図中、マークで示してあるのは、 それぞれ各 BIC の有炎燃焼開始および有炎燃焼終了の点で ある。また、着火遅れ期間、有炎燃焼期間、チャー燃焼期 間それぞれにおける、継続時間、重量減少量、平均重量減 少率、および残留灰分を Table 2 に示す。

Fig.6より、重量減少曲線は定性的には良く似た形状と なっていることがわかる。IC $100 \%$ に比べて、IC 50 \% + 


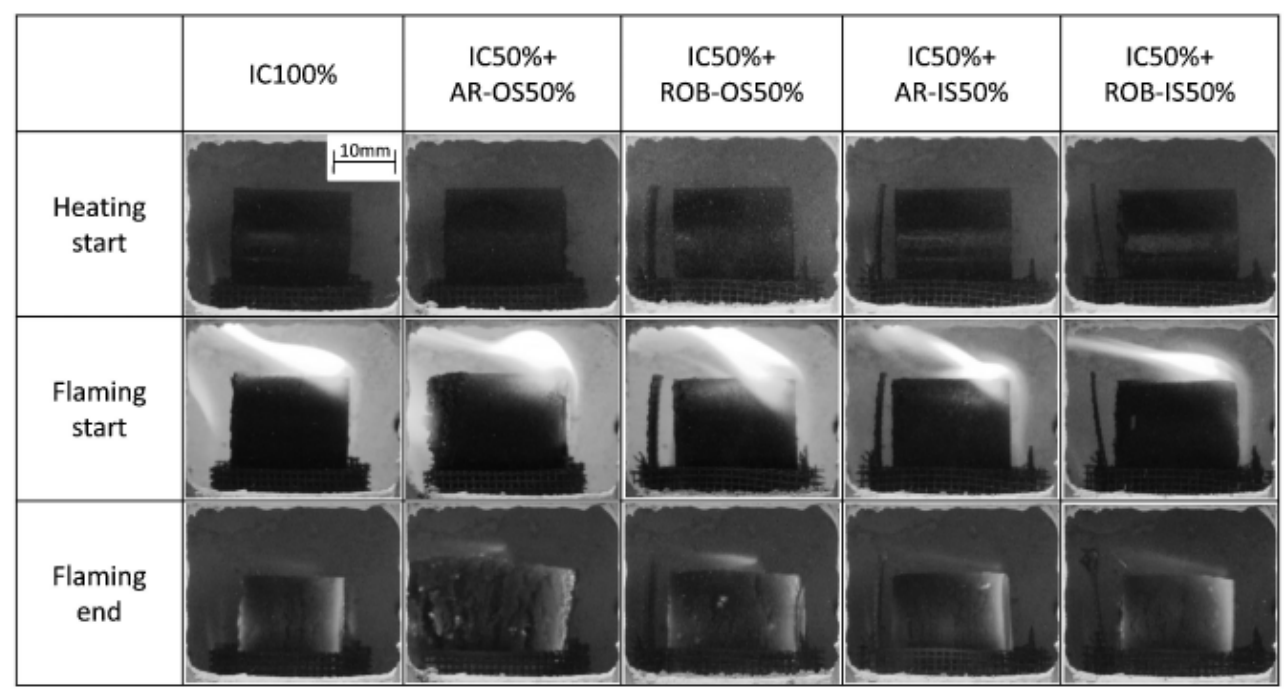

Fig. 7 Combustion behavior of the BICs

AR - OS 50 \% および IC $50 \%$ + ROB - OS 50 \%（以下、OS 配合 BIC と総称）は着火遅れがやや短縮されているのに対 して、IC 50 \% + AR - IS 50 \% および IC 50 \% + ROB - IS 50 \%（以下、IS 配合 BIC と総称）は着火遅れがやや延長され ている。また、試料投入から有炎燃焼終了までの時間は、 OS 配合 BIC、IS 配合 BIC ともにIC $100 \%$ に比べて短くなっ

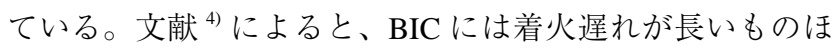
ど有炎燃焼期間の平均重量減少率が大きくなる傾向が報告 されている。Table 2 より、IC $100 \%$ と IS 配合 BIC の比較 では同様の傾向がみられるが、OS 配合 BIC では、着火遅 れが IC $100 \%$ より短いにもかかわらず、有炎燃焼期間の平 均重量減少率は IC $100 \%$ よりもやや高くなっている。この ことから、OS 配合 BIC では、IC $100 \%$ および IS 配合 BIC にはない事由により有炎燃焼期間の平均重量減少率が増加 している可能性がある。

Fig.7に各 BIC の加熱開始時、有炎燃焼開始時、有炎燃 焼終了時の写真を示す。これらの写真から、OS 配合 BIC は有炎燃焼終了時には多数の亀裂が生じ、円筒軸方向に試 料が膨張しているのに対して、IC $100 \%$ および IS 配合 BIC では多少の亀裂は見られるものの、ほとんど変形は見られ ないことが分かる。特に IC $50 \%+\mathrm{AR}-$ OS $50 \%$ の BIC は 有炎燃焼開始時に、既にいくらかの膨張が確認できる。加 熱・燃焼中の円筒軸方向の膨張が半径方向の膨張に比べて 大きいのは、BIC 製造時の圧縮が主に円筒軸方向に行われ ていることから、残留応力が半径方向に比べて円筒軸方向 に多く残っているためと考えられる。これらのことから、 各 BICの着火・燃焼挙動は原料それぞれの燃焼特性の違い に加えて、加熱・燃焼中に亀裂を生じることによる表面積 の変化の影響も考えられる。亀裂が発生すると、周囲の高 温ガスが BIC 内部に侵入しやすくなり、亀裂が発生しない
場合より、亀裂に沿った面積分広い表面積で加熱・熱分解 ガス化・表面反応が進行する結果、着火遅れおよび全体的 な燃焼時間が短縮されると推測される。

これらを確認するため、OS $100 \%$ (ロブス夕種)、およ びIS 100 \%（アラビカ、ロブスタ混合）のBICを、先の BIC と同じ製造条件で作製し燃焼実験を行った。その重量 減少曲線を、Fig.6中のIC $100 \%$ と共にFig.8に、加熱開始時、 有炎燃焼開始時および有炎燃焼終了時の写真を Fig.9 に示 す。また、着火遅れ期間、有炎燃焼期間、チャー燃焼期間 それぞれにおける、継続時間、重量減少量、平均重量減少率、 および残留灰分を Table 3 に示す。

Fig.8 より、IS $100 \%$ と IC $100 \%$ とは有炎燃焼期間の後 半に少しずれが見られる以外は、よく似た重量減少曲線で あるのに対して、OS $100 \%$ はそれらとかなり違った重量減 少曲線となっていることがわかる。

Fig.8 およびTable 3 より、OS $100 \%$ では IC $100 \%$ に 比べて着火遅れがかなり長くなっており、これは OS 配合 BIC の場合に IC $100 \%$ よも着火遅れがわずかながらも短 縮されたことと逆の傾向であると言える。Fig.6 と Fig.8の 比較から、OS 配合 BIC の重量減少曲線は OS $100 \%$ よりも IC $100 \%$ にかなり近い形状になっていることから、着火遅 れは、組成中の最も着火しやすい成分に強く影響されると 考えられる。しかし、より着火しにくい成分との混合によ り着火遅れが短縮されるとは考えにくい。このことから、 OS 配合 BIC の着火遅れの短縮は、成分の熱分解特性に起 因する影響に加えて、着火遅れ期間の加熱中に亀裂が生じ て反応表面積が増大することにより熱分解ガス化速度が増 加する影響も表れていると考えられる。Fig.7より、IC 50 $\%+\mathrm{AR}-\mathrm{OS} 50 \%$ では着火時にすでにBIC の膨張が見られ るため、この段階ですでに亀裂が発生しており、この影響 


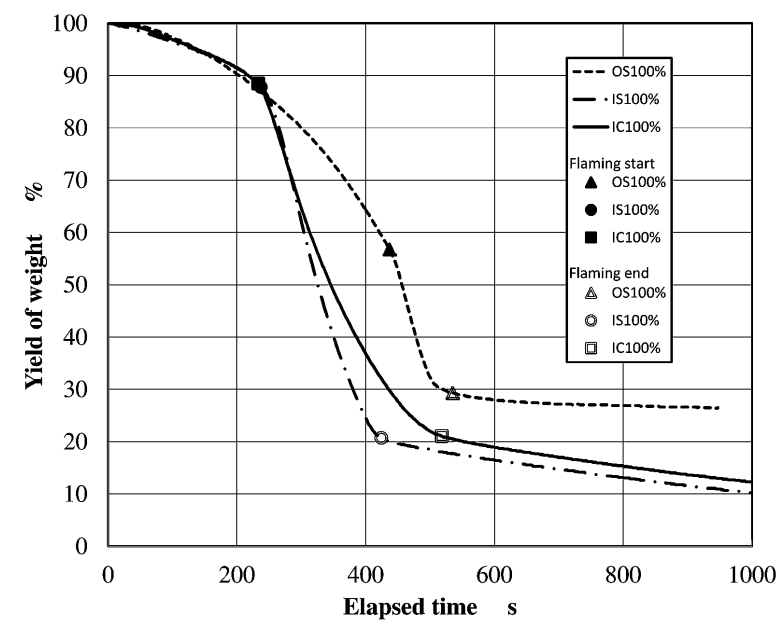

Fig. 8 Weight reduction curves for OS $100 \%$, IS $100 \%$ and IC $100 \%$ BICs at Tc $=698 \mathrm{~K}$

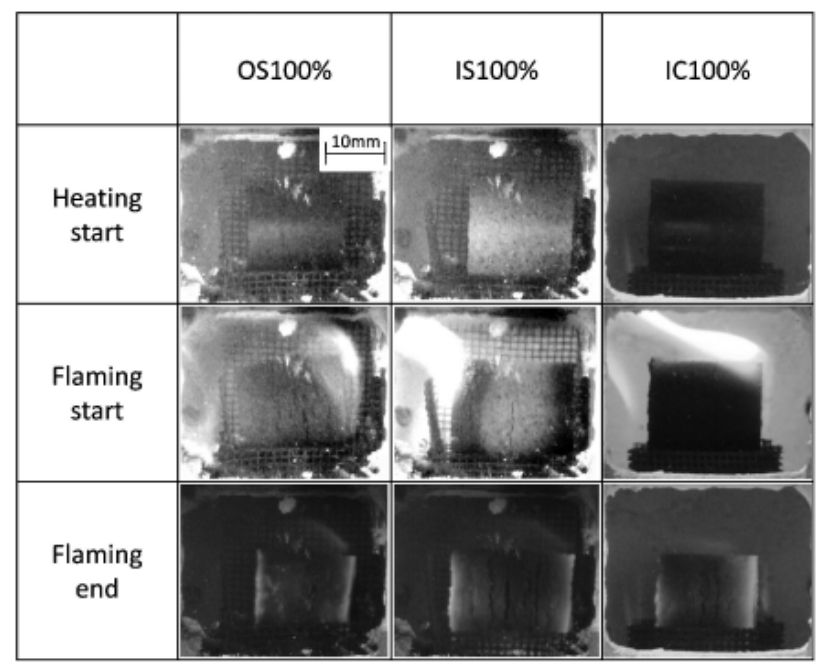

Fig. 9 Combustion behavior of OS, IS and IC BICs

Table 3 Combustion characteristic of IS, OS and IC BICs

\begin{tabular}{|c|c|c|c|c|c|c|c|c|c|c|}
\hline & \multicolumn{3}{|c|}{ Ignition delay term } & \multicolumn{3}{|c|}{ Flaming combustion term } & \multicolumn{3}{|c|}{ Char combustion term } & \multirow[b]{2}{*}{$\begin{array}{l}\text { Ash } \\
\text { \%wt }\end{array}$} \\
\hline & $\begin{array}{c}\text { Duration } \\
\text { time } \\
\text { s }\end{array}$ & $\begin{array}{c}\text { Weight } \\
\text { reduction } \\
\quad \%\end{array}$ & $\begin{array}{c}\text { Weight } \\
\text { reduction } \\
\text { rate } \\
\% / s\end{array}$ & $\begin{array}{c}\text { Duration } \\
\text { time } \\
\text { s }\end{array}$ & $\begin{array}{c}\text { Weight } \\
\text { reduction } \\
\quad \%\end{array}$ & $\begin{array}{l}\text { Weight } \\
\text { reduction } \\
\text { rate } \\
\% / s\end{array}$ & $\begin{array}{c}\text { Duration } \\
\text { time } \\
\text { s }\end{array}$ & $\begin{array}{c}\text { Weight } \\
\text { reduction } \\
\quad \%\end{array}$ & $\begin{array}{c}\text { Weight } \\
\text { reduction } \\
\text { rate } \\
\% / s\end{array}$ & \\
\hline OS $100 \%$ & 437 & 43.28 & 0.0990 & 98 & 27.45 & 0.280 & 412 & 2.80 & 0.00680 & 26.47 \\
\hline IS $100 \%$ & 237 & 12.18 & 0.0514 & 187 & 67.09 & 0.359 & 1757 & 20.03 & 0.0114 & 0.700 \\
\hline IC $100 \%$ & 233 & 11.49 & 0.0493 & 285 & 67.44 & 0.237 & 1769 & 18.65 & 0.0105 & 2.41 \\
\hline
\end{tabular}

による効果があったと考えられる。IC $50 \%+$ ROB - OS 50 \%では着火時には目立った膨張は確認できないが、IC 100 \%と比べた着火遅れの短縮幅が IC $50 \%+\mathrm{AR}-$ OS $50 \%$ に くらべて小さいことと、有炎燃焼終了時には亀裂発生およ び膨張が見られることから、明らかな膨張に到らないまで もわずかな亀裂が着火時にすでに発生しており、その影響 でわずかながら着火遅れが短縮されたと推測される。

一方、IS $100 \%$ は、着火遅れが IC $100 \%$ とほとんど差が ないにもかかわらず、その混合である IS 配合 BIC は着火 遅れがどちらよりも長くなっている。これは、Fig.7、9に おいて、IC 100 \%、IS 配合 BIC では着火時には BIC の亀裂 発生・膨張はほとんど見られないが、IS $100 \%$ では着火時 にすでに $10 \%$ 強の円筒軸方向への膨張が見られる。この ことから、IS $100 \%$ では着火に到るまでの段階ですでに亀 裂が発生していると考えられ、その龟裂に沿って高温空気 が侵入しやすくなり、亀裂が発生しない場合より広い表面 積で熱分解ガス化が進行した結果、着火遅れが短縮された と考えられる。よって、IS $100 \%$ において、IC $100 \%$ や IS 配合 BIC と同様に亀裂発生がなく成分の差のみが着火遅れ の差の要因であれば、もう少し着火遅れが長くなると推測 される。
有炎燃焼期間の平均質量減少率は IS $100 \%$ 、OS $100 \%$ 、 IC $100 \%$ の順で高く、これはIC 100 \%、OS 配合 BIC、IS 配合 BIC 間の平均質量減少率の関係と一致している。これ は一見妥当なようであるが、OS 配合 BIC および IS $100 \%$ は亀裂発生による反応表面積増大により着火遅れが短縮さ れていると考えられるので、有炎然焼期間も短縮されて良 いはずである。これは、先に述べた BICの特徴である、着 火遅れが長いものほど有炎燃焼期間の平均質量減少率が大 きくなる性質と相殺されたことにより、反応表面積増大の 効果が表れなかったものと考えられる。

チャー燃焼期間においては、OS $100 \%$ が他のBICに比 べて極端に平均重量減少率が小さくなっている。観察結果 において OS 100 \%だけは残留物が灰色ではなく黒褐色で あったことから、燃え残り・残炭分を多く含んだ残留物で あると見られた。成分分析によると、灰分は外皮で $5.6 \%$ 、 インスタントコーヒー製品がらで $1.6 \%$ であった。Table 2 より、IC $100 \%$ BIC では残留物は $2.41 \%$, OS 配合 BIC で は $3.83 \sim 4.38 \%$ となっており、BICの燃焼条件が成分分析 器における試料の燃焼条件より悪いことを考慮すればまず 妥当な結果と考えられるが、これに対して OS $100 \%$ BICの 残留物は $26.47 \%$ と明らかに多く、灰分以外の残留物が多 
スマートプロセス学会誌

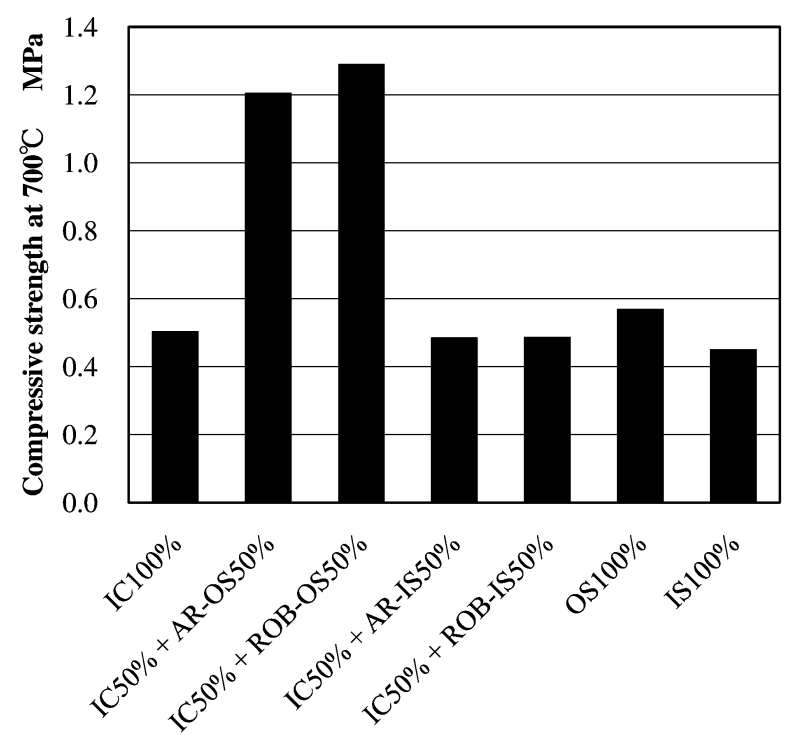

Fig. 10 Compressive strength at $700^{\circ} \mathrm{C}$

く含まれていると考えられる。これらのことから、OS 100 \%では高温分解成分を多く含むため、単体ではチャー燃焼 が維持できないが、燃焼性の良いIC 成分と混合した場合、 助燃の効果があり、IC $100 \%$ の燃焼特性に近い燃焼特性が 実現されたと考えられる。この OS $100 \%$ を除けば、IS 100 \% と OS 配合 BIC が他の BIC より $10 \sim 20 \%$ 程高い平均重 量減少率を示しているが、これは亀裂発生による反応表面 積増大の効果であると考えられる。

次に、亀裂発生の原因について考察する。亀裂発生の原 因としてまず思い当たるのが、成型時の粘結性の強弱であ る。これを検証するため、各 BIC の $700^{\circ} \mathrm{C}$ 䨌囲気下におけ る熱間圧縮強度を測定した。実験装置・方法は文献 ${ }^{5)}$ に従っ た。結果をFig.10に示す。この結果によると、Fig.8にお いて熱分解・燃焼特性の似通っていた IC、ISを成分とする IC $100 \%$ 、IS $100 \%$ および IS 配合 BICに関しては、圧縮強 度の弱いものほど有炎燃焼終了時の円筒軸方向の膨張が大 きく、粘結性の強弱が亀裂発生に影響していると考えられ る。しかし OS $100 \%$ は比較的高い圧縮強度を示し、有炎 燃焼終了時の円筒軸方向の膨張量も小さいが、OS 配合 BIC は他の BIC よりはるかに高い圧縮強度をもちながら、有炎 燃焼終了時の亀裂発生および円筒軸方向の膨張量は最大と なっている。OS 配合 BIC が他の BIC に比べて圧縮強度が はるかに高くなっている理由については別途検討が必要で あるが、このケースでは粘結性が悪いため燃焼過程で亀裂 を生じたとは考えにくい。その他の要因として、OS 配合 BIC は、Fig.8に見られるように、熱分解・燃焼特性がかな り違った成分の配合により構成されていることが考えられ る。このことから、OS 配合 BIC が燃焼中に多数の亀裂を
第 2 巻 第 2 号（2013 年 3 月）

生じたのは、熱分解・燃焼特性がかなり違った成分の混合 原料から成るため、ガス化・燃焼が表面から順序良く進行 せず、発生したガスがガス化のやや遅い成分の中に閉じ込 められる形になり、局所的な内圧上昇を起こした事が原因 ではないかと考えられる。また、圧縮強度が極端に高く計 測された理由としても、圧縮試験では円筒軸方向に圧縮荷 重をかけたため、粘結性による強度に加えて、この内圧上 昇分も荷重に対する反力に加わった可能性が考えられる。

\section{4. 結 論}

BIC は本来、石炭コークスの代替を目指して研究・開発 が行われてきたが、高密度燃料という性質も持ち合わせて おり、バイオマスの輸送性・貯蔵性を高める技術としても 有望であると考えられる。しかしコークス代替としては都 合のよい高硬度・難燃焼性が、通常燃料として利用する場 合には燃焼速度の低下につながり、用途を限定していた。 本研究において、輸送・貯蔵時の密度・硬度を保ったまま 燃焼性を改善できる方法が示されたことで、より広い用途 に対応できる然料に改良できる可能性がある。以下に本報 の結論を示す。

1. 熱分解・燃焼特性の異なる二成分を配合した BIC では、 全体的には燃焼性の良い方の成分に強く影響された燃焼 特性を示す。

2. BICの着火遅れおよびチャー燃焼期間の重量減少率は成 分の熱分解・燃焼特性だけでなく、燃焼中における亀裂 発生による反応表面積増大の影響を受ける。

3. BICの燃焼中における亀裂発生は、熱分解・燃焼特性の 異なる成分を配合することにより制御できる可能性があ る。

\section{謝 辞}

本研究の一部は、平成 23 年度 NEDO「バイオマスエネ ルギー技術研究開発／戦略的次世代バイオマスエネルギー 利用技術開発事業（次世代技術開発）」の助成により行われ た。ここに記して謝意を表する。

\section{参考文献}

1) 石井一義、村田博敏、桑名一徳、水野諭、森田明宏、井田民男、 高温学会誌、Vol. 35, No. 2 (2009), pp. 91-96.

2) 伊東弘行、酒井雄人、中原毅朗、井田民男、藤田修、スマー トプロセス学会誌、Vol. 1、No. 2 (2012), pp. 36-43.

3) 中井真伍、赤藤雄也、㴊端 学、井田民男、井上 優、第 49 回 燃焼シンポジウム講演論文集 (2011), pp. 156-157.

4) H.Ito, Y.Sakai, T.Ida, Y.Nakamura, O.Fujita, Proc. ASME/JSME 8th Thermal Engineering Joint Conference AJTEC2011 (2011), AJTEC2011-44145.

5) 水野 諭、井田民男、㴊端 学、難波邦彦、澤井 徹、日本実験 力学会講演論文集、No. 12 (2012)、pp.356-359. 